\title{
Synthesis of Branch-Type Cyclophane Tetramers Having a Multivalently Enhanced Guest-Binding Ability
}

\author{
Osamu Hayashida*, Chihiro Nada, Shuhei Kusano \\ Department of Chemistry, Faculty of Science, Fukuoka University, Nanakuma, Fukuoka, Japan \\ Email: ^hayashida@fukuoka-u.ac.jp
}

How to cite this paper: Hayashida, O., Nada, C. and Kusano, S. (2019) Synthesis of Branch-Type Cyclophane Tetramers Having a Multivalently Enhanced Guest-Binding Ability. Advances in Chemical Engineering and Science, 9, 76-86.

https://doi.org/10.4236/aces.2019.91006

Received: December 27, 2018

Accepted: January 20, 2019

Published: January 23, 2019

Copyright ( 2019 by author(s) and Scientific Research Publishing Inc. This work is licensed under the Creative Commons Attribution International License (CC BY 4.0).

http://creativecommons.org/licenses/by/4.0/

\section{Open Access}

\begin{abstract}
A cationic branch-type cyclophane tetramer (1a) was synthesized by introducing three Boc-protected cyclophane derivatives into a $\mathrm{N}$-acetylated tetraaza[6.1.6.1] paracy-clophane derivative as a core skeleton through DCC condensation, followed by removal of the external Boc-protecting groups. Cationic cyclophane tetramer 1a exhibited a high affinity toward an anionic and hydrophobic fluorescent guest, TNS, with binding constant of $4.8 \times 10^{5}$ $\mathrm{M}^{-1}$. This value of $1 \mathrm{a}$ was about 80 -fold larger than that of the corresponding monomeric cyclophane for the identical guest, reflecting multivalent effect on the guest binding. As for electrostatic recognition, the obtained binding constant of 1a was one order of magnitude larger than that of an analogous anionic cyclophane tetramer (1b) for the identical guest. These enhanced guest-binding abilities of 1a were easily evaluated by fluorescence titration experiments.
\end{abstract}

\section{Keywords}

Cyclophane, Host-Guest Chemistry, Multivalent Effect

\section{Introduction}

Cyclophane having an internal cavity is an inherent host that binds guest molecules to form host-guest complexes [1] [2] [3]. Much effort has been paid to develop water-soluble cyclophane derivatives to act as a host in water. Their guest-binding behaviors such as binding affinity and molecular recognition have been widely investigated [4] [5] [6]. In the process of forming host-guest complexes in water, hydrophobic interaction is supposed to be a major driving force [7]. Additionally, non-covalent interactions such as electrostatic and hydrogen bonding interactions become operative for molecular recognition [8] [9] [10]. 
However, hydrophobicity of the internal cavity provided by the simple-monomeric cyclophanes is not always enough to form stable host-guest complexes [11]. On the other hand, naturally occurring multivalent receptors on cell-surfaces are claimed to exhibit enhanced binding abilities toward their ligands [12] [13] [14]. Certainly, multiplying of the binding sites is a reasonable approach to increase the binding affinities toward guest molecules [15]. Recently, we have developed a liner-type cyclophane trimer, which was constructed with three macrocyclic skeletons and two connecting spacers [16]. Alternatively, we have also developed pendent-type cyclophane oligomers such as dimer, trimer, tetramer, and pentamer that were constructed with several macrocyclic skeletons and a peptide backbone [17]. Such liner- and pendent-type cyclophane oligomers show increased guest-binding abilities due to multivalent effects of macrocycles. In the course of our ongoing research on water-soluble hosts, we became interested in developing branch-type cyclophane oligomers, which are constructed with several macrocyclic skeletons in a branching fashion. Especially, it is interesting to compare the guest-binding behavior between branch- and pendent-type cyclophane oligomers. In addition, electrostatic interactions between these host and the guest molecules are regarded as an effective recognition factor. On these grounds, we designed branch-type cyclophane tetramers, $1 \mathrm{a}$ and $\mathbf{1 b}$, as cationic and anionic water-soluble hosts, respectively (Figure 1). In addition, we also designed cationic and anionic cyclophanes, $\mathbf{2 a}$ and $\mathbf{2 b}$, respectively, as a monomeric host (Figure 1). In this context, we report synthesis of $1 \mathrm{a}$ and $1 \mathbf{b}$ and their host-guest binding behavior from a viewpoint of multivalency effect and electrostatic recognition. This work has been directed toward the development of a new class of cyclophanes capable of performing sophisticated molecular recognition.

\section{Experimental Part}

\subsection{General Methods}

HEPES ( $N$-(2-hydroxyethyl) piperazine- $N$-2-ethane-sulfonic acid) buffer $(0.01 \mathrm{M}$, $\mathrm{pH}$ 7.4, with $0.15 \mathrm{M} \mathrm{NaCl}$ ) was purchased from GE Healthcare. The following compounds were obtained from commercial sources as guaranteed reagents and used without further purification: potassium

6-p-toluidinonaphthalene-2-sulfonate $[\mathrm{K}(\mathrm{TNS})]$ (from NacalaiTesque, Inc., Kyoto, Japan), 6-anilinonaphthalene-2-sulfonic acid (2,6-ANS) (from Molecular Probes, Eugene, OR). ${ }^{1} \mathrm{H}$ and ${ }^{13} \mathrm{C}$ spectra were taken on Bruker NMR AVANCE III 400 spectrometer. Fluorescence spectra, IR spectra, and MALDI TOF MS were recorded on JASCO FP-750, Perkin-Elmer spectrum one, and BrukerAutoflex Speed spectrometers, respectively.

\section{2. $N, N^{\prime}, N^{\prime \prime}$-Tris(Boc- $\beta$-alanyl)- $N^{\prime \prime}$-Acetyl-1,6,20,25-Tetraaza [6.1.6.1]-Paracyclophane 4}

Acetic anhydride $(0.5 \mathrm{~mL})$ was added to a solution of cyclophane derivative 


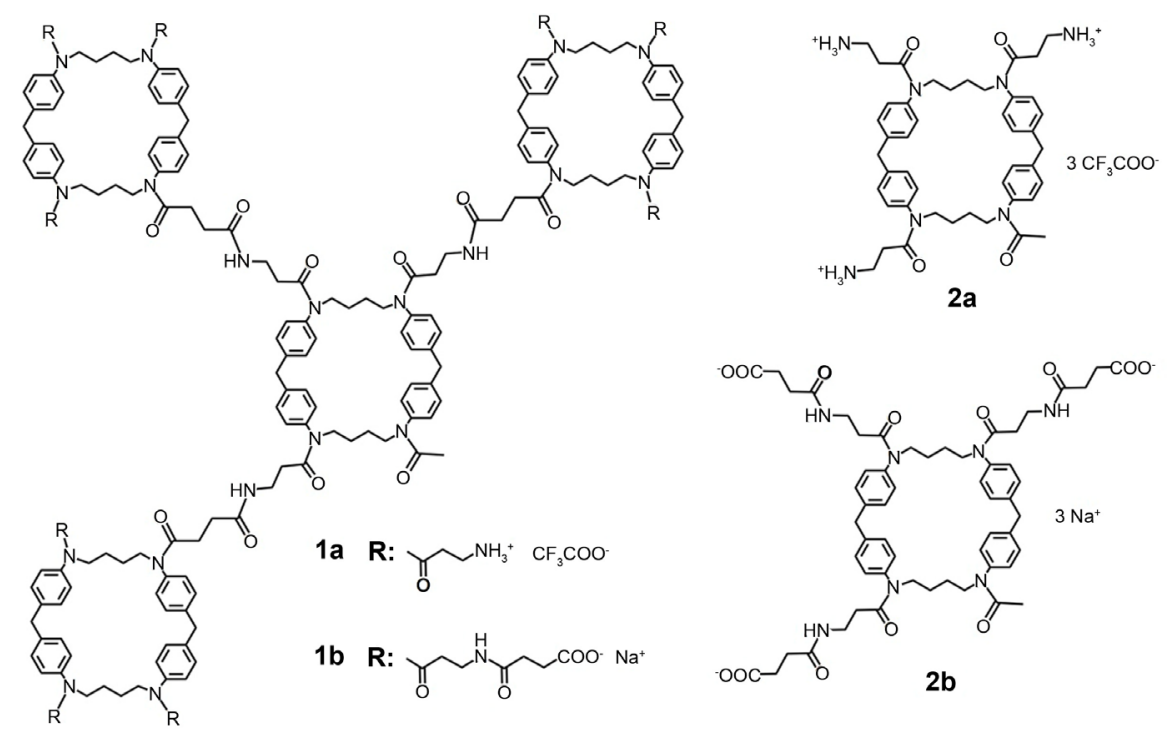

Figure 1 . Branch-type cyclophane tetramers (1a and $\mathbf{1 b})$ and monocyclic cyclophanes (2a and $2 \mathrm{~b})$.

bearing three Boc- $\beta$-Ala residues 3 (105 $\mathrm{mg}, 0.103 \mathrm{mmol}$ ) [15] in dry dichloromethane (DCM, $3 \mathrm{~mL}$ ) and resulting mixture was stirred for 2 hours at room temperature. Chloroform $(100 \mathrm{~mL})$ was added to the mixture, and then washed with $5 \%$ citric acid solution $(20 \mathrm{~mL})$. After being dried $\left(\mathrm{MgSO}_{4}\right)$, the solution was evaporated to dryness under reduced pressure. The residue was chromatographed on a column of silica gel $\left(\mathrm{SiO}_{2}\right)$ with ethyl acetate. Evaporation of the product fraction under reduced pressure gave a white solid $(75 \mathrm{mg}, 69 \%):{ }^{1} \mathrm{H}$ NMR $\left(400 \mathrm{MHz}, \mathrm{CDCl}_{3}, 298 \mathrm{~K}\right) \delta 1.42(\mathrm{~m}, 35 \mathrm{H}), 1.74(\mathrm{~s}, 3 \mathrm{H}), 2.09(\mathrm{~m}, 6 \mathrm{H})$, $3.25(\mathrm{~m}, 6 \mathrm{H}), 3.63(\mathrm{~m}, 8 \mathrm{H}), 3.96(\mathrm{~s}, 4 \mathrm{H}), 5.33(\mathrm{~s}, 3 \mathrm{H}), 6.95(\mathrm{~m}, 8 \mathrm{H})$, and 7.19 (d, $8 \mathrm{H}) .{ }^{13} \mathrm{C}$ NMR $\left(100 \mathrm{MHz}, \mathrm{CDCl}_{3}, 298 \mathrm{~K}\right) \delta 22.8,24.8,28.4,34.8,36.4,41.0$, 48.6, 79.0, 128, 130, 140, 141, 156, 170, and 171. IR $1645 \mathrm{~cm}^{-1}(\mathrm{C}=\mathrm{O})$. Found: $\mathrm{C}$, 67.68; H, 7.76; N, 9.19.Calcd for $\mathrm{C}_{60} \mathrm{H}_{81} \mathrm{~N}_{7} \mathrm{O}_{10}: \mathrm{C}, 67.96 ; \mathrm{H}, 7.70 ; \mathrm{N}, 9.25$. MALDI-TOF MS: $\mathrm{m} / \mathrm{z} 1083.4[\mathrm{M}+\mathrm{Na}]^{+}$, where $\mathrm{M}$ shows $\mathrm{C}_{60} \mathrm{H}_{81} \mathrm{~N}_{7} \mathrm{O}_{10}$.

\subsection{Cationic Cyclophane 2a}

Trifluoroacetic acid (TFA, $1.0 \mathrm{~mL}$ ) was added to a solution of $4(75 \mathrm{mg}$, $0.071 \mathrm{mmol})$ in dry DCM $(3 \mathrm{~mL})$, and the mixture was stirred for 2 hours at room temperature. Evaporation of the solvent under reduced pressure and the residue was purified by gel filtration chromatography on a column of Sephadex LH-20 with methanol as an eluent. Evaporation of the product fraction under reduced pressure gave a white solid (78 mg, quantitative): ${ }^{1} \mathrm{H} \mathrm{NMR}(400 \mathrm{MHz}$, $\left.\mathrm{CD}_{3} \mathrm{OD}, 298 \mathrm{~K}\right) \delta 1.45(\mathrm{~m}, 8 \mathrm{H}), 1.68(\mathrm{~s}, 3 \mathrm{H}), 2.29-2.41(\mathrm{~m}, 6 \mathrm{H}), 3.09(\mathrm{~m}, 6 \mathrm{H})$, $3.66(\mathrm{~m}, 8 \mathrm{H}), 4.02(\mathrm{~s}, 4 \mathrm{H}), 7.01-7.16(\mathrm{~m}, 8 \mathrm{H})$, and $7.34(\mathrm{~m}, 8 \mathrm{H}) .{ }^{13} \mathrm{C} \mathrm{NMR}$ $\left(100 \mathrm{MHz}, \mathrm{CD}_{3} \mathrm{OD}, 298 \mathrm{~K}\right) \delta 22.7,25.7,32.4,36.9,41.7,49.7,130,132,141,143$, 171, and 173. IR $1634 \mathrm{~cm}^{-1}(\mathrm{C}=\mathrm{O})$. Found: $\mathrm{C}, 53.99 ; \mathrm{H}, 5.81 ; \mathrm{N}, 8.65$. Calcd for $\mathrm{C}_{51} \mathrm{H}_{60} \mathrm{~F}_{9} \mathrm{~N}_{7} \mathrm{O}_{10} \cdot 2 \mathrm{H}_{2} \mathrm{O}: \mathrm{C}, 53.82 ; \mathrm{H}, 5.67 ; \mathrm{N}$, 8.62. MALDI-TOF MS: $\mathrm{m} / \mathrm{z} 760.9$ [M $+\mathrm{H}]^{+}, 782.9[\mathrm{M}+\mathrm{Na}]^{+}$, where $\mathrm{M}$ shows $\mathrm{C}_{45} \mathrm{H}_{57} \mathrm{~N}_{7} \mathrm{O}_{4}$ as a free amine. 


\subsection{Anionic Cyclophane 2b}

To a solution of cyclophane $2 \mathrm{a}(83 \mathrm{mg}, 0.075 \mathrm{mmol})$ and triethylamine (TEA, 1 $\mathrm{mL})$ in dry DCM $(3 \mathrm{~mL})$ was added succinic anhydride $(45 \mathrm{mg}, 0.45 \mathrm{mmol})$. The mixture was stirred for 4 days at room temperature. The solution was distilled off under reduced pressure to give a white solid. The residue was purified by gel filtration chromatography on a column of Sephadex LH-20 with methanol as an eluent. The resulting salt was converted into the sodium salt by ion-exchange chromatography on a column of Amberlite IR-120 with methanol as an eluent. Evaporation of the product fraction under reduced pressure gave a white solid. (53 mg, 63\%): ${ }^{1} \mathrm{H}$ NMR (400 MHz, $\left.\mathrm{CD}_{3} \mathrm{OD}, 298 \mathrm{~K}\right) \delta 1.41(\mathrm{~m}, 8 \mathrm{H}), 1.66(\mathrm{~s}, 3 \mathrm{H})$, $2.17(\mathrm{t}, 6 \mathrm{H}), 2.39(\mathrm{~m}, 12 \mathrm{H}), 3.07(\mathrm{~m}, 6 \mathrm{H}), 3.68(\mathrm{~m}, 8 \mathrm{H}), 4.02(\mathrm{~m}, 4 \mathrm{H}), 6.97(\mathrm{~m}$, $8 \mathrm{H})$, and $7.30(\mathrm{~m}, 8 \mathrm{H}) .{ }^{13} \mathrm{C} \mathrm{NMR}\left(100 \mathrm{MHz}, \mathrm{CD}_{3} \mathrm{OD}, 298 \mathrm{~K}\right) \delta 22.7,25.6,33.7$ 35.2, 36.6, 41.7, 49.5, 129, 131, 141, 142, 172 - 175, and 180. IR $1634 \mathrm{~cm}^{-1}(\mathrm{C}=\mathrm{O})$. Found: C, 57.73; H, 5.99; N, 8.61. Calcd for $\mathrm{C}_{57} \mathrm{H}_{66} \mathrm{~N}_{7} \mathrm{Na}_{3} \mathrm{O}_{13} \cdot 3 \mathrm{H}_{2} \mathrm{O}: \mathrm{C}, 58.01 ; \mathrm{H}$, 6.15; N, 8.31. MALDI-TOF MS: $\mathrm{m} / \mathrm{z} 1059.3[\mathrm{M}-\mathrm{H}]^{-}, 1083.1[\mathrm{M}+\mathrm{Na}]^{+}$where $\mathrm{M}$ shows $\mathrm{C}_{57} \mathrm{H}_{69} \mathrm{~N}_{7} \mathrm{O}_{13}$.

\subsection{A precursor of 1, Boc-Protected Cyclophane Tetramer 6}

Dicyclohexylcarbodiimide (DCC, $72 \mathrm{mg}, 0.35 \mathrm{mmol}$ ) was added to a solution of Boc-protected cyclophane having a carboxylic acid 5 [15] (378 mg, $0.34 \mathrm{mmol}$ ) in dry DCM $(3 \mathrm{~mL})$ at $0^{\circ} \mathrm{C}$, and the mixture was allowed to stand at the same temperature while being stirred for $20 \mathrm{~min}$. The mixture was added to a solution of $2 \mathrm{a}$ (102 $\mathrm{mg}, 0.093 \mathrm{mmol})$ in dry DCM $(2 \mathrm{~mL})$, and the resulting mixture was stirred for 5 days at room temperature. Precipitates that formed ( $N, N$-dicyclohexylurea) were removed by filtration, the solvent was eliminated under reduced pressure, and the residue was dissolved in ethyl acetate (EtOAc, $10 \mathrm{~mL}$ ). Insoluble materials were removed by filtration, and the filtrate was evaporated to dryness under reduced pressure. The residue was chromatographed on a column of silica gel $\left(\mathrm{SiO}_{2}\right)$ with chloroform-methanol $=9: 1 \mathrm{v} / \mathrm{v}$ as an eluent. Evaporation of the product fraction under reduced pressure and the residue was purified by gel filtration chromatography on a column of Sephadex LH-20 with methanol as an eluent. Evaporation of the product fraction under reduced pressure gave a white solid (123 mg, 33\%): ${ }^{1} \mathrm{H}$ NMR (400 MHz, $\left.\mathrm{CDCl}_{3}, 298 \mathrm{~K}\right) \delta 1.43(\mathrm{~m}, 113 \mathrm{H}), 1.76$ (s, $3 \mathrm{H}), 2.09(\mathrm{~m}, 24 \mathrm{H}), 2.24(\mathrm{~m}, 6 \mathrm{H}), 2.38(\mathrm{~m}, 6 \mathrm{H}), 3.31(\mathrm{~m}, 24 \mathrm{H}), 3.63(\mathrm{~m}, 32$ $\mathrm{H}), 3.96(\mathrm{~s}, 16 \mathrm{H}), 5.33(\mathrm{~s}, 9 \mathrm{H}), 6.59(\mathrm{~s}, 3 \mathrm{H}), 7.01(\mathrm{~m}, 32 \mathrm{H})$, and $7.21(\mathrm{~m}, 32 \mathrm{H})$. ${ }^{13} \mathrm{C}$ NMR $\left(100 \mathrm{MHz}, \mathrm{CDCl}_{3}, 298 \mathrm{~K}\right) \delta 22.8,24.9,28.4,29.9,31.3,34.8,41.0,48.7$, 78.9, 128, 130, 140, 156, and 172. IR $1644 \mathrm{~cm}^{-1}(\mathrm{C}=\mathrm{O})$. Found: C, 67.56; H, 7.59; $\mathrm{N}$, 9.54. Calcd for $\mathrm{C}_{231} \mathrm{H}_{300} \mathrm{~N}_{28} \mathrm{O}_{37} \cdot 3 \mathrm{H}_{2} \mathrm{O}$ : C, 67.42; H, 7.50; N, 9.53. MALDI-TOF MS: $\mathrm{m} / \mathrm{z} 4084.5[\mathrm{M}+\mathrm{Na}]^{+}$, where $\mathrm{M}$ shows $\mathrm{C}_{231} \mathrm{H}_{300} \mathrm{~N}_{28} \mathrm{O}_{37}$.

\subsection{Cationic Cyclophane Tetramer 1a}

TFA $(1.0 \mathrm{~mL})$ was added to a solution of $6(60 \mathrm{mg}, 0.015 \mathrm{mmol})$ in dry DCM (3 $\mathrm{mL}$ ), and the mixture was stirred for 2 hours at room temperature. Evaporation 
of the solvent under reduced pressure and the residue was purified by gel filtration chromatography on a column of Sephadex LH-20 with methanol as an eluent. Evaporation of the product fraction under reduced pressure gave a white solid (50 mg, 81\%): ${ }^{1} \mathrm{H}$ NMR (400 MHz, $\left.\mathrm{CD}_{3} \mathrm{OD}, 298 \mathrm{~K}\right) \delta 1.42(\mathrm{~m}, 32 \mathrm{H}), 1.62$ (s, $3 \mathrm{H}), 2.01-2.24(\mathrm{~m}, 24 \mathrm{H}), 2.39(\mathrm{~m}, 12 \mathrm{H}), 3.03(\mathrm{~m}, 18 \mathrm{H}), 3.25(\mathrm{~m}, 6 \mathrm{H}), 3.67$ $(\mathrm{m}, 32 \mathrm{H}), 4.01(\mathrm{~s}, 16 \mathrm{H}), 6.92-7.16(\mathrm{~m}, 32 \mathrm{H})$, and $7.32(\mathrm{~m}, 32 \mathrm{H}) .{ }^{13} \mathrm{C} \mathrm{NMR}(100$ $\left.\mathrm{MHz}, \mathrm{CD}_{3} \mathrm{OD}, 298 \mathrm{~K}\right) \delta 22.6,25.4,30.8,31.7,32.5,35.1,36.8,41.7,49.2,129$, 131, 140, 141, 142, 143, 171, 173, and 174. IR $1644 \mathrm{~cm}^{-1}(\mathrm{C}=\mathrm{O})$. Found: C, 57.43; $\mathrm{H}, 6.00 ; \mathrm{N}$, 9.11. Calcd for $\mathrm{C}_{204} \mathrm{H}_{237} \mathrm{~F}_{27} \mathrm{~N}_{28} \mathrm{O}_{37} \cdot 5 \mathrm{H}_{2} \mathrm{O}: \mathrm{C}, 57.30 ; \mathrm{H}, 5.82 ; \mathrm{N}, 9.17$. MALDI-TOF MS: $\mathrm{m} / \mathrm{z} 3161.5[\mathrm{M}+\mathrm{H}]^{+}, 3183.5[\mathrm{M}+\mathrm{Na}]^{+}$, where $\mathrm{M}$ shows $\mathrm{C}_{186} \mathrm{H}_{228} \mathrm{~N}_{28} \mathrm{O}_{19}$ as a free amine.

\subsection{Anionic Cyclophane Tetramer $1 \mathrm{~b}$}

To a solution of cyclophane $1 \mathrm{a}(81 \mathrm{mg}, 0.019 \mathrm{mmol})$ and triethylamine (TEA, 1 $\mathrm{mL})$ in dry DCM $(3 \mathrm{~mL})$ was added succinic anhydride $(35 \mathrm{mg}, 0.346 \mathrm{mmol})$. The mixture was stirred for 4 days at room temperature. The solution was distilled off under reduced pressure to give a white solid. The residue was purified by gel filtration chromatography on a column of Sephadex LH-20 with methanol as an eluent. The resulting salt was converted into the sodium salt by ion-exchange chromatography on a column of Amberlite IR-120 with methanol as eluent. Evaporation of the product fraction under reduced pressure gave a white solid. (50 mg, 61\%): ${ }^{1} \mathrm{H}$ NMR (400 MHz, CD $\left.30 D, 298 \mathrm{~K}\right) \delta 1.42(\mathrm{~m}, 32 \mathrm{H}), 1.65$ (s, 3 H), 2.12 - $2.28(\mathrm{~m}, 36 \mathrm{H}), 2.39(\mathrm{~m}, 18 \mathrm{H}), 2.53(\mathrm{~m}, 18 \mathrm{H}), 3.31(\mathrm{~m}, 24 \mathrm{H}), 3.66$ $(\mathrm{m}, 32 \mathrm{H}), 3.99(\mathrm{~m}, 16 \mathrm{H}), 6.99(\mathrm{~m}, 32 \mathrm{H})$, and $7.29(\mathrm{~m}, 32 \mathrm{H}) .{ }^{13} \mathrm{C}$ NMR $(100$ $\left.\mathrm{MHz}, \mathrm{CD}_{3} \mathrm{OD}, 298 \mathrm{~K}\right) \delta 23.0,25.5,30.5$ - 31.6, 35.1, 36.6, 41.7, 49.9, 129, 131, 141, 142, 172 - 174, and 176. IR $1633 \mathrm{~cm}^{-1}(\mathrm{C}=\mathrm{O})$. Found: $\mathrm{C}, 59.83 ; \mathrm{H}, 6.34 ; \mathrm{N}$, 8.84. Calcd for $\mathrm{C}_{222} \mathrm{H}_{255} \mathrm{~N}_{28} \mathrm{Na}_{9} \mathrm{O}_{46} \cdot 10 \mathrm{H}_{2} \mathrm{O}$ : C, 60.07; $\mathrm{H}, 6.25 ; \mathrm{N}$, 8.84. MALDI-TOF MS: $\mathrm{m} / \mathrm{z} 4059.1[\mathrm{M}-\mathrm{H}]^{-}, 4083.6[\mathrm{M}+\mathrm{Na}]^{+}$where $\mathrm{M}$ shows $\mathrm{C}_{222} \mathrm{H}_{264} \mathrm{~N}_{28} \mathrm{O}_{46}$.

\subsection{Binding Constants of Cyclophane with Fluorescence Guests}

To each solution of TNS and 2,6-ANS $(1.0 \mu \mathrm{M})$ in HEPES buffer were added increasing amounts of the hosts such as $1 \mathbf{a}, \mathbf{1 b}, \mathbf{2 a}$, and $\mathbf{2 b}$. The fluorescence spectra were recorded after each addition of the hosts. The binding constants were calculated on the basis of the Benesi-Hildebrand method for titration data.

\section{Results and Discussion}

\subsection{Synthesis of Branch-Type Cyclophane Tetramers}

We designed cationic and anionic cyclophane tetramers (1a and $\mathbf{1 b}$ ) as a branch-type host (Figure 1). The cyclophane tetramers are composed of four tetraaza[6.1.6.1]paracyclophane derivatives. Three external cyclophane derivatives are connected to a core cyclophane through an alkyl spacer having amide linkages. Hydrophilic polar side chains were introduced onto nine nitrogen atoms of the external cyclophanes to afford water-solubility on the resulting 
hosts, while one of nitrogen atoms on the core cyclophane was acetylated. Cationic and anionic cyclophane tetramers, $1 \mathrm{a}$ and $1 \mathrm{~b}$, have cationic ammonium and anionic carboxylate groups, respectively. Both cyclophane tetramers are expected to act as a water-soluble host having internal hydrophobic cavities. In addition, in order to compare its guest-binding ability, we also designed cationic and anionic cyclophanes (2a and $\mathbf{2 b}$ ) as a monomeric host. These hosts were prepared based on Boc chemistry by following the reaction sequence given in Scheme 1. Cationic cyclophane 2a was prepared from acetylation of $N, N^{p}, N^{\prime \prime}$-tris(Boc- $\beta$-alanyl)-1,6,20,25-tetraaza[6.1.6.1]paracyclophane (3) [16] with acetic anhydride, followed by removal of the Boc-protecting groups with TFA. A precursor of 1a, Boc-protected cyclophane tetramer 6 was prepared by condensation of $2 \mathrm{a}$ with three equivalent of Boc-protected cyclophane having a carboxylic acid $\mathbf{5}$ in the presence of dicyclohexylcarbodiimide (DCC). Cationic cyclophane tetramer $1 \mathrm{a}$ was obtained by removal of the protecting groups with TFA. Both anionic cyclophanes $1 \mathrm{~b}$ and $\mathbf{2 b}$ were obtained from $1 \mathrm{a}$ and $2 \mathrm{a}$, respectively, by a reaction with succinic anhydride. All new compounds were purified by gel filtration chromatography and identified by ${ }^{1} \mathrm{H}$ and ${ }^{13} \mathrm{C} N M R$ and MALDI-TOF MS spectroscopy as well as by elemental analysis. Cationic cyclophane

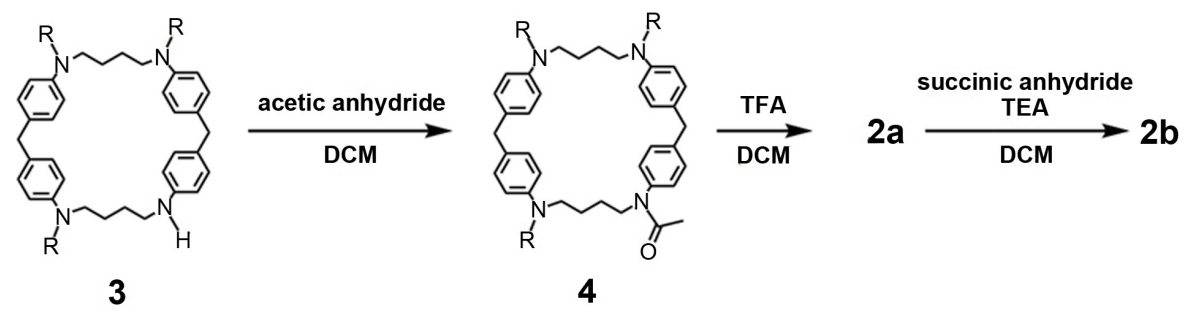<smiles>[R]C(=[R])CCNC(=O)OC(C)(C)C</smiles>
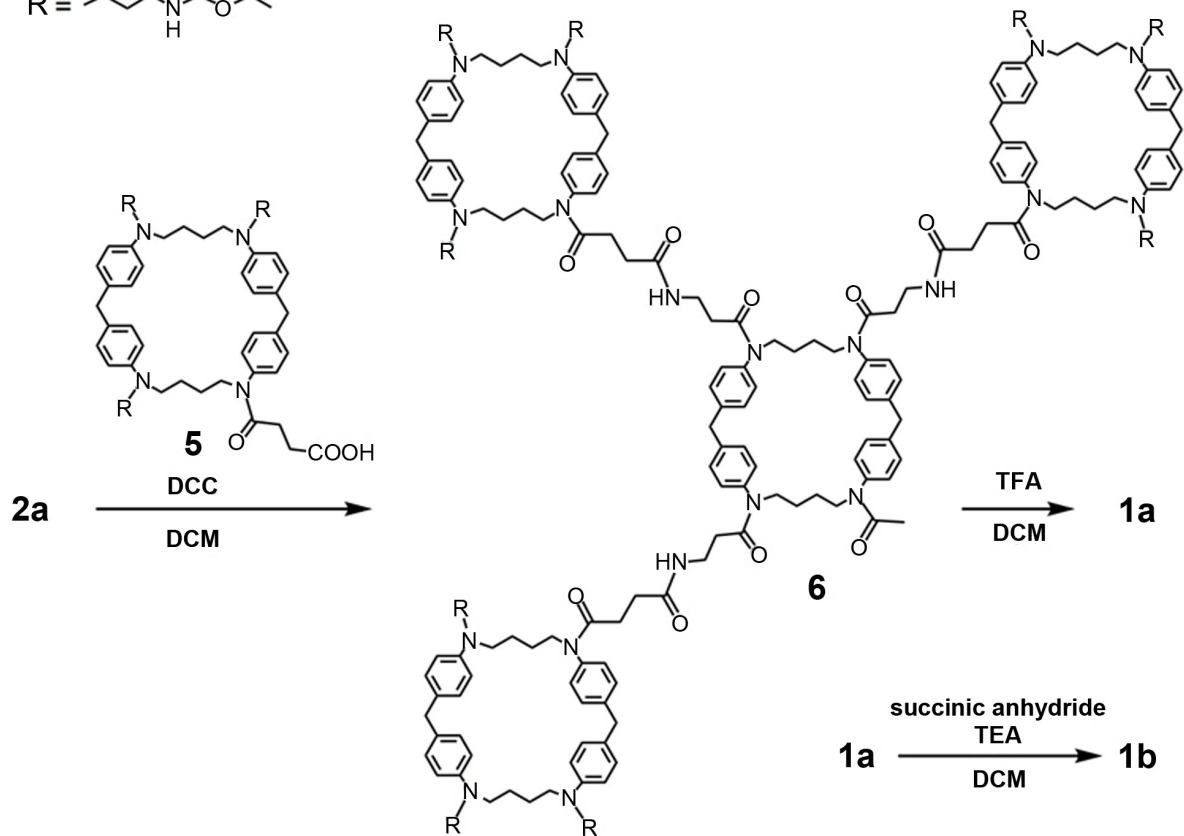

Scheme 1. Preparation of cyclophanes 1a, 1b, 2a, and 2b. 
tetramer 1a had good water-solubility of $0.4 \mathrm{~g} / \mathrm{mL}$. At least at concentrations below $60 \mu \mathrm{M}$ of 1a, a good linear Beer's plot of absorbance at $232 \mathrm{~nm}$ was obtained, which indicates that $1 \mathrm{a}$ was not self-aggregated. A similar property in the water-solubility of $\mathbf{1 b}, \mathbf{2} \mathbf{a}$, and $\mathbf{2 b}$ was also observed by identical methods.

\subsection{Binding Behavior for Fluorescence Guests}

Cyclophane tetramers provide four hydrophobic internal cavities for organic guest molecules in water, while monomeric cyclophanes haveone hydrophobic internal cavity. Therefore, the guest-binding abilities of cyclophane tetramers are expected to be larger than those of monomeric cyclophanes, reflecting multivalent effect [11]. In addition, it is expected that electrostatic attraction between the hosts and the guests is an effective driving force for molecular recognition. That is, the peripheral side chains such as cationic ammonium and anionic carboxylate groups are expected to play an important role for guest recognition.

In order to evaluate the guest-binding behavior of $1 \mathrm{a}$, fluorescence titration experiments were executed by using anionic and hydrophobic guests such as 6-p-toluidinonaphthalene-2-sulfonate (TNS) and 6-anilinonaphthalene-2-sulfonate (2,6-ANS) in an aqueous HEPES (0.01 M, pH 7.4, with $0.15 \mathrm{M} \mathrm{NaCl}$ ) buffer (Figure 2). These guests are well-known fluorescent probes, which exhibits intensive fluorescence in non-polar solvents, but with low fluorescence intensity in water [18]. Upon addition of an excess amount of 1a to the HEPES buffer containing TNS, a fluorescence intensity at around $433 \mathrm{~nm}$ originating from TNS increased, reflecting formation of the corresponding host-guest complex, as shown in Figure 3(a). Such experimental conditions at an excess amount of 1a are favorable for the formation of 1:1 host:guest complexes of 1a with the guest. The stoichiometry for the complex was actually confirmed to be 1:1 host:guest by Job's continuous variation method. Binding constant for the formation of 1:1 host:guest complexes $(K)$ of 1a with TNS was evaluated to be $4.8 \times 10^{5} \mathrm{M}^{-1}$ on the basis of the Benesi-Hildebrand relationship [19], and listed in Table 1. The fluorescence titration experiments toward TNS were executed by using $1 \mathrm{~b}, 2 \mathrm{a}$, and $2 \mathrm{~b}$ (Figures $3(\mathrm{~b})-(\mathrm{d})$, respectively) and the corresponding $K$ values are summarized in Table 1. In a comparison between the guest-binding abilities of 1a and monomeric host $2 \mathrm{a}$, the saturated fluorescence intensities upon complexation of 1a with TNS were much larger than those by $2 \mathrm{a}$, as shown in Figures 3 (a)-(c). The $K$ value of 1a with TNS was about 80 -fold larger than that of 2 a with the identical guest, reflecting multivalent effect (Table 1).

Comparison between the guest-binding abilities of cationic host $1 \mathrm{a}$ and anionic host $1 \mathrm{~b}$ gave us meaningful information as regards electrostatic interactions between the hosts and the guests. The saturated fluorescence intensities upon complexation of $1 \mathrm{~b}$ with TNS were much smaller than those by 1a (Figure 3(a) and Figure 3(b)). The $K$ values of $1 \mathrm{~b}$ toward these guests were 1 order of magnitude weaker than those of $1 \mathrm{a}$ due to electrostatic repulsion between the anionic host and anionic guests (Table 1). Similar guest recognition based on electrostatic interactions was observed between monomeric cyclophanes $\mathbf{2 a}$ and $\mathbf{2 b}$ 


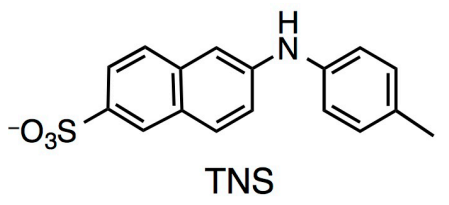<smiles>O=S(=O)(Oc1ccccc1)c1ccc2cc(Nc3ccccc3)ccc2c1</smiles>

Figure 2. Hydrophobic fluorescent guests TNS and 2,6-ANS.
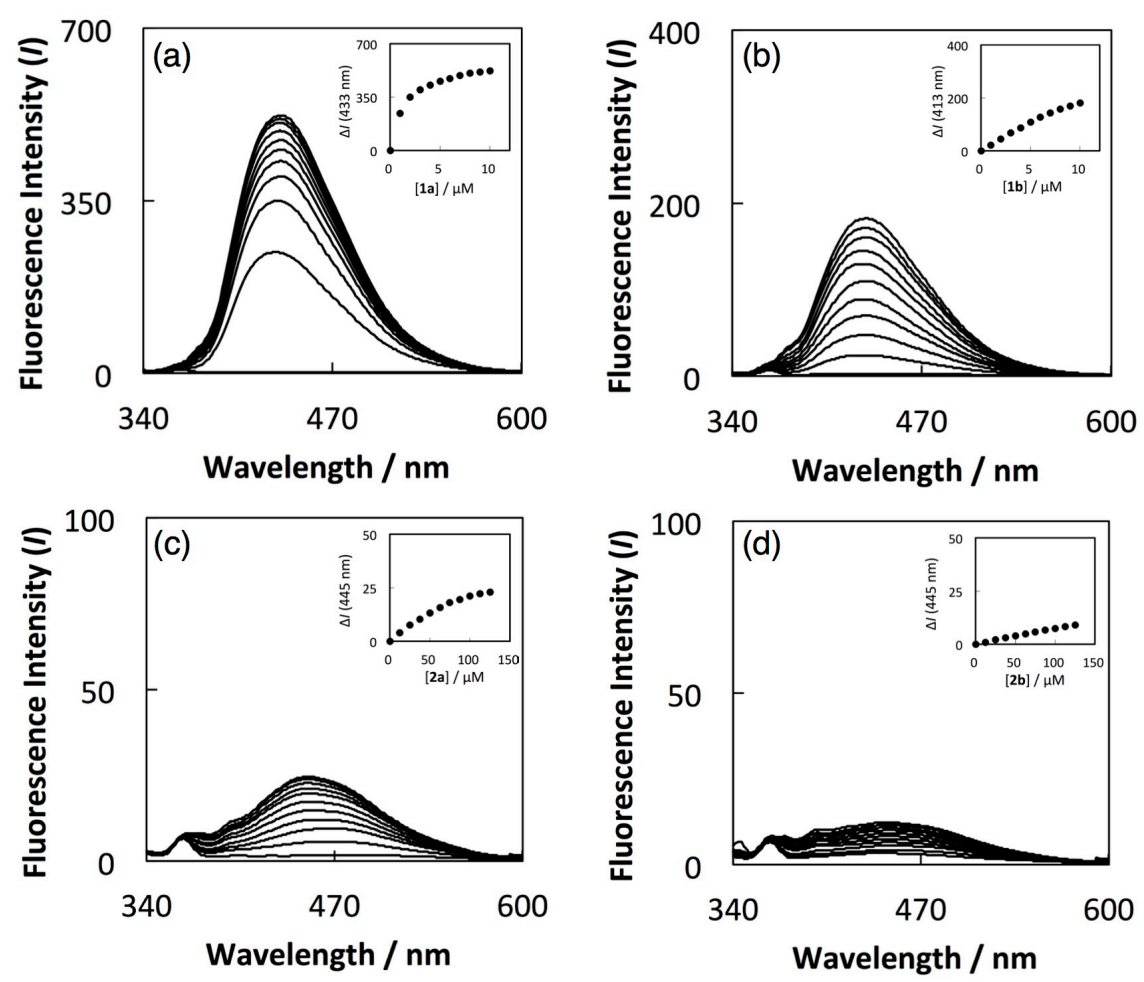

Figure 3. Fluorescence spectra for aqueous solutions of TNS upon addition of the hosts: $\mathbf{1 a}(\mathrm{a}), \mathbf{1 b}(\mathrm{b}), \mathbf{2 a}(\mathrm{c})$, and $\mathbf{2 b}$ (d) in HEPES buffer at $298 \mathrm{~K}$ : [TNS] $=1.0 \mu \mathrm{M},[\mathbf{1} \mathbf{a}]=[\mathbf{1 b}]$ (from bottom to top) $=0.1 .0,2.0,3.0,4.0,5.0,6.0,7.0,8.0,9.0$, and $10.0 \mu \mathrm{M}$. [2a] $=[2 \mathrm{~b}]$ (from bottom to top) $=0.12 .5,25.0,37.5,50.0,62.5,75.0,87.5,100,113$, and $125 \mu \mathrm{M}$. Ex, $326 \mathrm{~nm}$. Inset: correlations between fluorescence intensity and host concentrations.

Table 1. Binding constants $\left(K, \mathrm{M}^{-1}\right)$ for host-guest complexes in HEPES buffer at $298 \mathrm{~K}^{\mathrm{a}}$

\begin{tabular}{ccc}
\hline Host & \multicolumn{2}{c}{$K, \mathrm{M}^{-1}$} \\
\cline { 2 - 3 } & TNS & 2,6 -ANS \\
\hline $1 \mathrm{a}$ & $4.8 \times 10^{5}$ & $2.6 \times 10^{5}$ \\
\hline $\mathbf{b}$ & $3.5 \times 10^{4}$ & $2.4 \times 10^{4}$ \\
$2 \mathrm{a}$ & $6.1 \times 10^{3}$ & $4.4 \times 10^{3}$ \\
$2 \mathbf{b}$ & $1.8 \times 10^{3}$ & $0.9 \times 10^{3}$ \\
$\mathrm{C}_{5}{ }^{\mathrm{b}}$ & $4.8 \times 10^{5}$ & $2.5 \times 10^{5}$ \\
$\mathrm{C}_{4}{ }^{\mathrm{b}}$ & $2.7 \times 10^{5}$ & $1.9 \times 10^{5}$ \\
$\mathrm{C}_{3}{ }^{\mathrm{b}}$ & $1.7 \times 10^{5}$ & $6.7 \times 10^{4}$ \\
$\mathrm{C}_{2}{ }^{\mathrm{b}}$ & $5.4 \times 10^{4}$ & $3.0 \times 10^{4}$
\end{tabular}

${ }^{\mathrm{a}}$ Excitation: 326 and $318 \mathrm{~nm}$ for TNS and 2,6-ANS, respectively. ${ }^{\mathrm{b}}$ Reference [17]. 
(Figure 3(c) and Figure 3(d), Table 1). In addition, the above-mentioned multivalent effect on the guest binding was observed between anionic cyclophanes $1 b$ and $2 b$ (Figure $3(b)$ and Figure $3(d)$ ), Table 1 ). Therefore, $1 \mathrm{a}$ was found to be most desired host exhibiting both multivalent effect and favorable electrostatic interactions among the adopted hosts for TNS binding. Similar enhancements of $1 b$ in the guest-binding ability were also observed, when 2,6-ANS was employed as a guest (Table 1 ).

In addition, we compared the guest-binding behavior between branch-type cyclophane tetramer 1a and pendent-type cyclophane oligomers $C_{n}$ [17] (Figure 4). The $K$ values of 1a with TNS and 2,6-ANS were larger than those of $\mathrm{C}_{4}$ and comparable to those of $\mathrm{C}_{5}$ (Table 1 ). These results suggested that molecular design of branch-type cyclophane oligomers was more suitable for multivalently enhanced guest-binding exhibition than that of pendent-type cyclophane oligomers.

\section{Conclusion}

We have synthesized a cationic branch-type cyclophane tetramer (1a) by introducing three Boc-protected cyclophane derivatives into a $\mathrm{N}$-acetylated tetraaza[6.1.6.1] paracy-clophanederivative as a core skeleton through DCC condensation, followed by removal of the external Boc-protecting groups. Cationic cyclophane tetramer 1a exhibited a high affinity for fluorescent guests such as TNS, and 2,6-ANS with binding constants of $4.8 \times 10^{5}$ and $2.6 \times 10^{5} \mathrm{M}^{-1}$, respectively. These values of 1a were about 80 - and 60 -fold larger than those of the corresponding monomeric cyclophane for the identical guests, respectively, reflecting multivalent effect on the guest binding. As for electrostatic recognition, the obtained binding constants of $1 \mathrm{a}$ were one order of magnitude larger than those of an analogous anionic cyclophane tetramer (1b) for the identical guests. It was found that molecular design of branch-type cyclophane oligomers was more suitable for multivalently enhanced guest-binding exhibition than that of the previous pendent-type cyclophane oligomers. We believe that our concept on

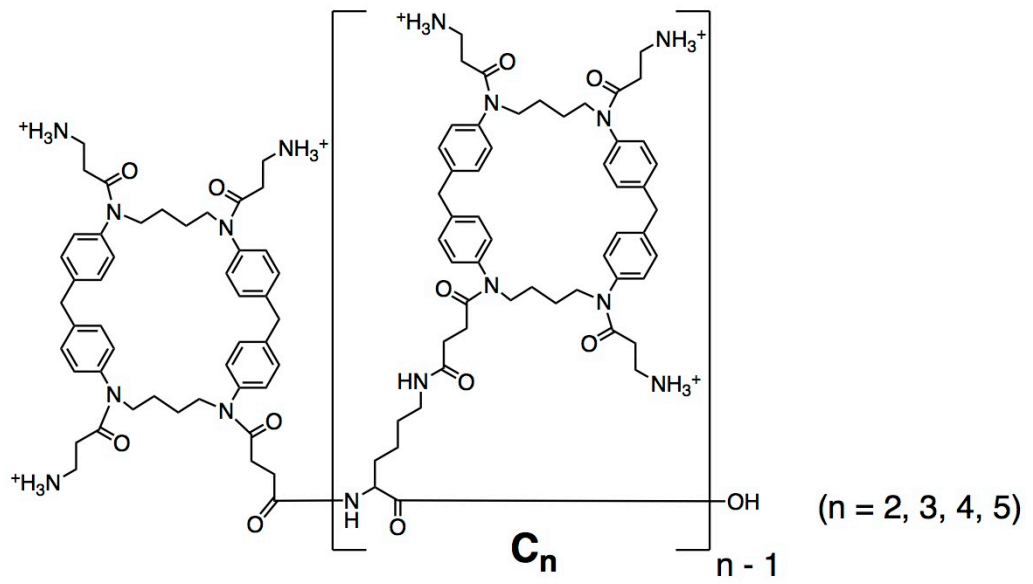

Figure 4. Pendent-type cyclophane oligomers $C_{n}$ [17]. 
molecular design of multivalency effect in macrocycles provides a useful guidepost for developments of host carriers having strong binding affinities toward anticancer drugs as a guest.

\section{Acknowledgements}

The present work is partially supported by Grant-in-Aid (No. 16K05761) from the Ministry of Education, Culture, Science, Sports and Technology of Japan.

\section{Conflicts of Interest}

The authors declare no conflicts of interest regarding the publication of this paper.

\section{References}

[1] Wu, N.W., Petsalakis, I.D., Theodorakopoulos, G., Yu. Y. and Rebek Jr., J. (2018) Cavitands as Containers for $\alpha, \omega$-Dienes and Chaperones for Olefin Metathesis. Angewandte Chemie International Edition, 57, 15091-15095. https://doi.org/10.1002/anie.201808265

[2] Liu, Z., Krishna, S., Nalluri, M. and Stoddart, J.F. (2017) Surveying Macrocyclic Chemistry: From Flexible Ccrown Ethers to Rigid Cyclophanes. Chemical Society Reviews, 46, 2459-2478. https://doi.org/10.1039/C7CS00185A

[3] Seward, E., Hopkins, R.B., Sauerer, W., Tam, S.-W. and Diederich, F. (1990) Redox-Dependent Binding Ability of a Flavin Cyclophane in Aqueous Solution: Hydrophobic Stacking Versus Cavity-Inclusion Complexation. Journal of the American Chemical Society, 112, 1783-1790. https://doi.org/10.1021/ja00161a020

[4] Georgiadis, T.M., Georgiadis, M.M. and Diederich, F. (1991) Synthesis and Complexation Properties of a Water-Soluble Optically Active Cyclophane Incorporating a 4-Naphthyl-1,2,3,4-Tetrahydroisoquinoline Unit as a Chiral Spacer. The Journal of Organic Chemistry, 56, 3362-3369. https://doi.org/10.1021/jo00010a034

[5] Barwell, N.P., Crump, M.P. and Davis, A.P. (2009) A Synthetic Lectin for Beta-Glucosyl. Angewandte Chemie International Edition, 48, 7673-7676. https://doi.org/10.1002/anie.200903104

[6] Ariga, K., Nakanishi, T., Terasaka, Y., Tsuji, H., Sakai, D. and Kikuchi, J. (2005) Piezoluminescence at The Air-Water Interface through Dynamic Molecular Recognition Driven by Lateral Pressure Application. Langmuir, 21, 976-981. https://doi.org/10.1021/la0477845

[7] Murakami, Y., Hayashida, O., Ono, K. and Hisaeda, Y. (1993) Thermodynamic and Geometrical Characterization of Molecular Recognition by Cage-Type and Peptide Azapara-Cyclophanes in Aqueous Media. Pure \& Applied Chemistry, 65, 2319-2324. https://doi.org/10.1351/pac199365112319

[8] Yu, G., Han, C., Zhang, Z., Chen, J., Yan, X., Zheng, B., Liu S. and Huang, F. (2012) Pillar[6]arene-Based Photoresponsive Host-Guest Complexation. Journal of the American Chemical Society, 134, 8711-8717. https://doi.org/10.1021/ja302998q

[9] Nunez-Dallos, N., Reyes, A. and Quevedo, R. (2012) Hydrogen Bond Assisted Synthesis of Azacyclophanes from L-Tyrosine Derivatives. Tetrahedron Letters, 53, 530-534. https://doi.org/10.1016/j.tetlet.2011.11.086

[10] Huskens, J., Mulder, A., Auletta, T., Nijhuis, C.A., Ludden, M.J.W. and Reinhoudt, D.N. (2004) A Model for Describing the Thermodynamics of Multivalent 
Host-Guest Interactions at Interfaces. Journal of the American Chemical Society, 126, 6784-6797. https://doi.org/10.1021/ja049085k

[11] Hayashida, O. and Nakamura, Y. (2013) Synthesis of Water-Soluble Cyclophane Pentamers Using Click Chemistry as a Multivalent Host for Daunorubicin and Doxorubicin. Bulletin of the Chemical Society of Japan, 86, 223-229. https://doi.org/10.1246/bcsj.20120296

[12] Lee, Y.C., Lee, R.T., Rice, K., Ichikawa, Y. and Wong, T.C. (1991) Topography of Binding Sites of Animal Lectins: Ligands' view. Pure \& Applied Chemistry, 63, 499-506. https://doi.org/10.1351/pac199163040499

[13] Lee, Y.C. and Lee, R.T. (1995) Carbohydrate-Protein Interactions: Basis of Glycobiology. Accounts of Chemical Research, 28, 321-327. https://doi.org/10.1021/ar00056a001

[14] Sigal, G.B., Mammen, M., Dahmann, G. and Whitesides, G.M. (1996) Polyacrylamides Bearing Pendant $\alpha$-Sialoside Groups Strongly Inhibit Agglutination of Erythrocytes by Influenza Virus: The Strong Inhibition Reflects Enhanced Binding through Cooperative Polyvalent Interactions. Journal of the American Chemical Society, 118, 3789-3800. https://doi.org/10.1021/ja953729u

[15] Hayashida, O. and Sato, D. (2008) Preparation and Multivalently Enhanced Guest-Binding Affinity of Water-Soluble Cyclophane Heptadecamers. The Journal of Organic Chemistry, 73, 3205-3211. https://doi.org/10.1021/jo800129j

[16] Hayashida, O. and Kitaura, A. (2006) Synthesis of Water-Soluble Tris(cyclophane) Hosts and Surface Plasmon Resonance Study on Guest-Binding Interaction with Immobilized Guests. Chemistry Letters, 35, 808-809.

https://doi.org/10.1246/cl.2006.808

[17] Hayashida, O. and Nakashima, T. (2012) Synthesis of Peptide-Based Cyclophane Oligomers Having Multivalently Enhanced Guest-Binding Affinity. Bulletin of the Chemical Society of Japan, 85, 715-723. https://doi.org/10.1246/bcsj.20120076

[18] Slavik, J. (1982) Anilinonaphthalene Sulfonate as a Probe of Membrane Composition and Function. Biochimica et Biophysica Acta (BBA)-Reviews on Biomembranes, 694, 1-25.

https://www.sciencedirect.com/science/article/pii/0304415782900120

[19] Benesi, H.A. and Hildebrand, J.H. (1949) A Spectrophotometric Investigation of the Interaction of Iodine with Aromatic Hydrocarbons. Journal of the American Chemical Society, 71, 2703-2707. https://doi.org/10.1021/ja01176a030 